\title{
Developing cooperative integrated reading and composition- based role-playing game application as an alternative media in the reading learning
}

\author{
Nina Sofiana \\ ninasofiana@unisnu.ac.id \\ Universitas Islam Nahdlatul Ulama Jepara \\ Jl. Taman Siswa (Pekeng) Tahunan Jepara, Central Java, Indonesia
}

Received: July 1, 2018; Accepted: September 20, 2018; Published: September 24, 2018

\begin{abstract}
The objective of this study is to develop Role-Playing Game (RPG) application as an alternative media in reading learning. The developed RPG application is based on Cooperative Integrated Reading and Composition (CIRC). The implementation of the developed RPG application is aimed to provide learning materials of reading skill in more attractive way to generate an innovative learning environment in which the students will not be uninterested in the learning process. The study is education research and development (R\&D) which consisted of research and information collecting, planning, developing product form, expert validation, product revision, field testing and developing final product. The subjects are the students and English teachers from one of vocational schools in Pati, Central Java, Indonesia. The instruments of this research are observation, documentation and questionnaire. Using qualitative and quantitative data analysis, the media developed contained some texts and it belonged to good category as the result of validation from material and media experts. After the developed media was used in reading learning, it was found that the students had positive response toward it. Thus, it can be deduced that the RPG application developed can be used as a media in learning process of reading skill.
\end{abstract}

Keywords: reading, learning media, role-playing game (RPG), cooperative integrated reading and composition (CIRC) 
How to cite this paper: Sofiana, N. (2018). Developing cooperative integrated reading and composition-based role-playing game application as an alternative media in the reading learning. Journal on English as a Foreign Language, 8(2), 170188. doi:http://dx.doi.org/10.23971 亿efl.v8i2.887

DOI: http://dx.doi.org/10.23971 ßefl.v8i2.887

Reading is one of the important skills of English which has prominent position in foreign language teaching. It provides valuable contribution to developing learners' language acquisition and supports other skills of foreign language (Dickinson, Griffith, Golinkoff, \& Hirsh-Pasek, 2012). By reading, learners will discover grammatical knowledge and develop vocabularies and therefore all skills of English will increase. Dickinson et al. (2012) also confirms clearly that reading affect learners' language development. Thus, students have to be skilful in reading; they have to be able to read effectively and efficiently, both to learn something and 'to learn how to learn'. Not only the students, should teacher also give appropriate strategy in reading that will teach them to be more skilful and efficient readers. Otherwise, students still face a lot of problems.

The requirements of efficient readers are more apparent for and it is needed by the students at elementary and intermediate levels. It is also including the students of Vocational High School (VHS), due to their role as learners of English as foreign language. For students of VHS, reading is definitely needed to master, in which they have to read particular text dealing with their vocation in order to acquire information related to their field study which is useful in communication in the future profession (Dewi, 2018). The problem arises then is whether or not the students of VHS have been efficient readers.

Observation done in the preliminary study showed that the reading skills of the students of VHS seemed to have not been satisfactory yet. The indication could be seen when they were asked to read an English text. They frequently spent more time looking in a dictionary than read the text. Moreover, when they were tested to answer to the questions related to the text, most of them only quoted some parts of the text, giving no indication that they knew what they were doing, and thus the answers were not relevant with the questions

Whether or not the students of VHS have been efficient readers, it is actually the duty of the teacher to give instruction so as to make them so. Nasab, Esmaeili, and Sarem (2015) explain that teachers need to use teaching 


\section{Nina Sofiana}

aids to give explanation of language meaning and construction, keep student in a topic, or as the basis of a whole activity. This is not only because their urgent ongoing needs to pass the final exams, or for study purposes, but also because they need to prepare themselves to communicate using English in their work field. However, based on the researcher's preliminary observation, teaching and learning process of reading was mostly dominated by the teacher by tutoring. The teaching media used by the teacher in teaching reading were monotonous and did not support the teaching and learning process because the teacher only focused more on the use of textbook and students' worksheet (LKS). Consequently, these activities make them bored and have less attention to their lesson.

The use of media in the teaching and learning process is very beneficial to attract students' attention and to make teaching and learning activities more interesting and also effective (Preeti, 2014). She also adds that it is very helpful to increase students' interest and attention in learning. However, in selecting the proper media in teaching and learning process, of course, it should be tailored to the characteristics of today's learners. Nowadays, students are encircled by all sorts of media like computers, television, DVD, video games, and internet in their everyday life. They generally have a very different tendency from previous generations in which all of their activities are greatly influenced in digital technology (Prensky, 2003). They tend to spend more hours not only in front of computer screens, but also digital music and video players, mobile phones, video games, and other gizmos that require technology.

Based on the above phenomenon, Digital Game-Based Learning (DGBL) can be used as an alternative learning model which is expected to improve students' English proficiency especially reading skill. DGBL is a software application used to support learning by utilizing games (Brom, Sisler, \& Slavik, 2010). Digital Game is a form of entertainment, and therefore, this game is an effective medium to motivate students to be actively involved in learning activities (Prensky, 2003).

Many studies have shown the effectiveness of digital game media in the learning process. The use of DGBL-based computer media has a significant effect in teaching and learning process or training process, because it can improve student's motivation and performance by increasing interest in modelled learning (Hussain, Tan, \& Idris, 2014; Iacovides, Aczel, Scanlon, Taylor, \& Woods, 2011; La Guardia, Gentile, Dal Grande, Ottaviano, \& Allegra, 2014; Panoutsopoulos \& Sampson, 2012).

Role-Playing Game (RPG) application is the most suitable application that can expose the students to the language skills and integrate them in an interesting way that could ensure the students to immerse them in the story 


\section{Nina Sofiana}

(Cruz, 2007). It is an electronic application of computer and/or laptop that can be used as media in teaching and learning process of English as a foreign language. DeHaan (2011) gets the students to design and develop English language RPG. The result of this design project shows that students learns and practises a variety of language. The project also provides many opportunities for authentic discussions in the foreign language. Another study on RPG is also conducted by Irfan, Ihsan, and Petrus (2016). They conclude that RPG is an effective media to teach students' vocabulary. Students unconsciously acquire new vocabularies while enjoying the game. Thus, the English vocabulary achievement is improved.

From synthesising the need of the students of VHS to be efficient readers and the importance of media in the teaching and learning process, the objective of the study is to develop RPG application as media in reading learning for vocational high school students. It is expected that the result of this study is able to provide an alternative media in teaching and learning process which is appropriate to the students' need and interest to keep them interested and motivated during reading activities.

\section{METHOD}

\section{Research Design}

This study employs the educational research and development (R\&D) since the objective of this study is to develop RPG application as media in reading learning for vocational high school students. One of the objectives of the educational research and development is to create a product like audiovisual game for education purpose. Therefore, in line with the objective of the study, this study was adapted from the research and development proposed by the experts, Borg and Gall who conducted their research in 1983.

The ten steps of the research and development including research and information collection, planning, preliminary form of product, preliminary field-testing, main product revision, main field-testing, operational product revision, operational field-testing, final product revision, and dissemination and implementation. However, in this study, it is simplified into following phases and described in Figure 1 because of the time limitation in conducting the research.

The first phase is the research and information collecting. In this stage, the writer reviews the literature which relates to the topic comprising learning media, Role-Playing Game (RPG), and English curriculum for Vocational High School. The writer also observes and documents lesson plan, materials, and textbooks to find the teaching and learning condition in the class. In addition, the writer analyses the teachers' and students' needs in English learning to the 


\section{Nina Sofiana}

teachers and the students. The result of this needs analysis is used as a reference in developing DGBL model in the form of RPG.

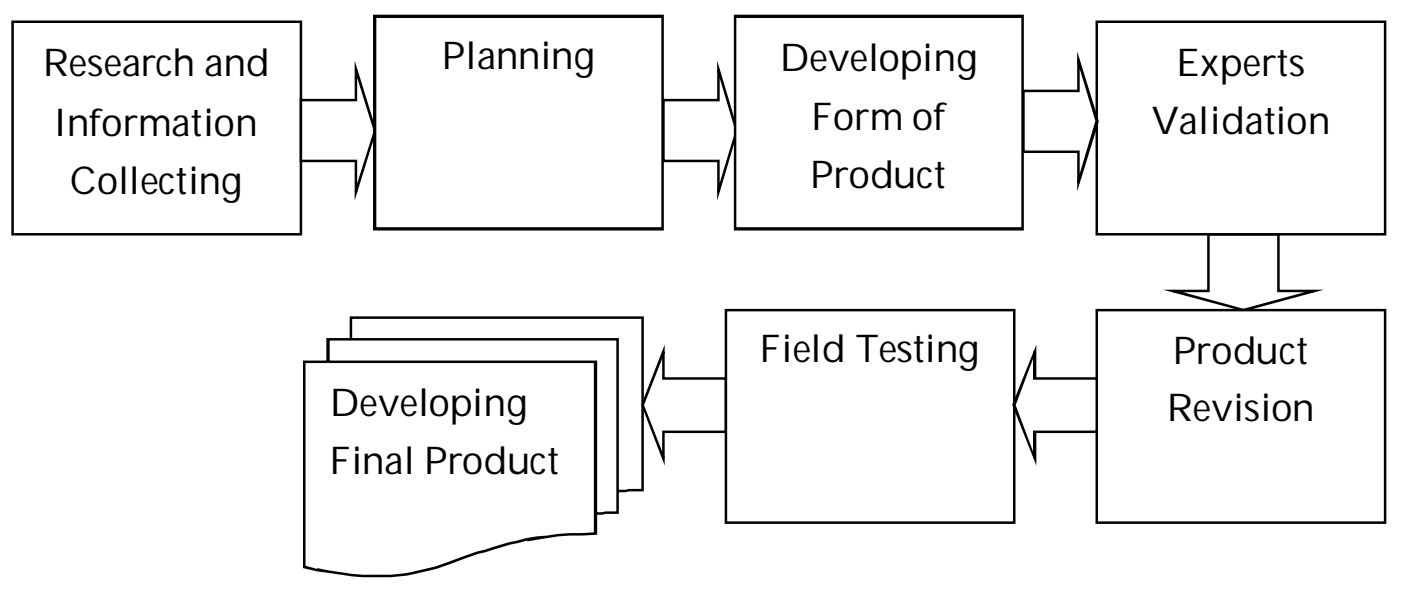

Figure 1. The Methodological Framework of the Study

The next is planning phase by formulating teaching objectives, teaching activities, and reading materials. The following phase is developing form of product, followed by experts' validation and revision. The result of validation from the media experts and material experts is used to revise the product.

After validation from media and materials experts, it is continued with field testing. The field testing consists of limited and expanded try-out. The limited try-out is conducted toward ten grade students of vocational high school to use RPG as media of learning. After evaluation and revision of limited try-out result, the expanded try-out is conducted toward thirty-three students in one class. The result of expanded try-out is also used as basis for the last product revision. The product of the this research is computer application made using RPG movie maker which its activities adapts the elements of CIRC program developed by the experts, Stevens, Madden, Slavin, and Farnish who developed CIRC program in 1987. It originally comprises three principal elements: basal-related activities, direct instruction in reading comprehension, and integrated language arts and writing. The product developed in this study adapts only basal-related activities because the focus of this study is to develop and design media in reading learning.

\section{Instruments and Data Collection}

The instruments used to collect data in this study are observation, questionnaire and documentation. The researcher conducted an observation 


\section{Nina Sofiana}

and a documentation of lesson plan, materials, and textbooks to find the preliminary teaching and learning condition in the classroom.

To find the data of the teachers' and students' needs in English learning, questionnaires were administered to the teachers and the students. Five teachers and 69 tenth-grade students from one of vocational schools in Pati, Central Java, Indonesia participated in this study. The teachers' questionnaire is related to the teaching and learning process of reading, the use of computer or media in reading learning, and the teachers' needs. Meanwhile, the students' questionnaire includes some aspects of things students do outside the schools, reading learning activities, the use of computer or media, and their needs in learning process of reading. In addition, the questionnaire is also directed to the experts to validate the product. It modifies the questionnaire used by (Findawati, 2014). The media experts validates the media focusing on the software engineering and visual communication, while material experts focusing on learning design of concept, material, and implementation. The questionnaire is given to the students to find out their perception toward the developed media. It consists of three aspects of programming, program security, user interaction and reaction, and learning.

\section{Data Analysis}

In this study, the data are analysed both qualitatively and quantitatively. Qualitatively, it is used to analyze data and information obtained from preliminary studies through observation and documents. The use of qualitative descriptive analysis is intended to obtain the learning process undertaken by the teacher and the needs of the ideal learning model learning from the teachers' and students' perspective. The analysis includes the stages of data collection, data reduction, data display, and conclusion drawing/verification.

Furthermore, descriptive statistics is used to analyse the questionnaire. The quantitative data, then, is converted to qualitative data on scale of 5 . It can be described in Table 1 (Wahyuni, 2017).

Table 1. Conversion Criteria of Quantitative Data to Qualitative Data

\begin{tabular}{ccc}
\hline Percentage & Qualification & Discussion \\
\hline $90-100$ & Very good & No need revision \\
\hline $75-89$ & Good & Need revision \\
\hline $65-74$ & Enough & Need revision \\
\hline $55-64$ & Poor & Need revision \\
\hline $0-54$ & Very poor & Need revision \\
\hline
\end{tabular}




\section{FINDINGS}

\section{Research and Information Collection}

In the research and information collection, the researcher reviewed the literature, conducted an observation to find the condition of learning process, and analysed the teachers' and students' needs. By reviewing the literature related to the topic, it was found that Role-Playing Game (RPG) is one type of game that can be developed for learning activities. Therefore, learning activities by utilizing RPG can be categorized as a digital game-based learning. Digital Game-Based Learning (DGBL) is a learning method that uses game apps that have been specifically designed to aid the learning process. By using DGBL, learners will get stimulus in learning that is emotional, intellectual, and psychomotor. DGBL is one of the learning methods that is considered suitable with the condition of the digital generation today. DGBL can be an attractive alternative learning strategy to create a fun environment. Support of multimedia elements such as text, images, sound, animation, and video is more interesting because it can produce maximum visualization. Moreover, the availability of devices to run the game applications is more varied and widespread.

In addition, Cooperative Integrated Reading and Composition (CIRC) is one of the learning strategies of English that asks students to be able to integrate the ability to read and write in English. Students will be able to write if students are able to comprehend the reading well. This is because reading will provide ideas or information when students have to string words in writing. Reading also needs individual skills required by students, such as skimming and scanning. In order for students to have an interest in reading learning activities, it is necessary to have a learning media that can create a fun learning condition. By using CIRC-based RPG application as an alternative media to teach reading, students are expected to have more opportunities in exploring reading skills.

Then, in the observation, the researcher observed the English teacher and the students related to learning of reading skill. This observation activity focused on the methods and media used by English teachers, while for the students it focused on students' responses toward the learning activities. The result of observation showed that the school applied the 2013 curriculum. The teacher used scientific approach in learning activities, which consists of five basic learning experiences: 1) observing, 2) questioning, 3) experimenting, 4) associating, and 5) communicating. In the learning process, first, the teacher gave a model of how to read the text the textbook and students were asked to imitate. Then students were trained to ask about the difficult vocabularies contained in the text. Finally, students are invited to understand the text and answer the questions in the text. 


\section{Nina Sofiana}

Based on the observation result, students had a poor response toward the learning activities. It could be seen when they were asked to answer questions related to the text. They still got difficulties in finding the answers. They even did not have any motivation to answer. This was mainly due to the use of monotonous learning strategy. The media used by the teacher also did not attract the attention of students to learn the material given. Students got bored because teachers only used textbook in the learning process.

The last was needs analysis of teachers and students. The needs of teachers were obtained from questionnaires results to teachers relating to learning process of English reading skill that has been done by teachers. The results showed teachers often experience some obstacles. This was proven by the number of students who had to follow remedial activities for reading skills $(72 \%)$. It indicated that most of students had low ability in reading. This difficulty was related to students' interest in learning. Students were less motivated to learn reading skills due to lack of vocabulary mastery. In addition, the availability of media that could be used to support the learning process of English reading skill that could attract student interest was still very limited. As a result, teachers found it difficult to get media that matched the theme. Therefore, the implementation of learning was often done with the lecturing method where the textbook was a major learning resource for students.

In the analysis of student needs it was obtained a description of the learning implementation of reading skills in the classroom. Students had difficulty in understanding the content of the text because they had no knowledge of the content of the text and often found difficult vocabulary in the text given by the teacher. These difficulties were caused by low student learning motivation. They were lazy to open the dictionary so that students were passive and just waited for the teacher to help them to translate the difficult vocabulary they encountered. All they need is teachers using interesting media and learning methods so that they will enjoy more in the learning process.

\section{Planning and Developing Form of Product}

In this phase, the researcher first formulated reading materials, teaching objectives, and teaching activities for the game. Based on the 2013 curriculum, various types of texts have been used to improve students' attitudes, knowledge and skills in communicating with English in accordance with their core competencies and defined basic competencies. Some types of text are narrative, procedure, descriptive, report, news items, analytical exposition, persuasive exposition, spoof, explanation, discussion and review. Meanwhile, the type of text that should be taught for grade $\mathrm{X}$ of VHS is recount, narrative, and descriptive. Based on the results of interviews with teachers, the selected text 


\section{Nina Sofiana}

for the game was narrative because the students' reading skill of narrative text was still low. In addition, this text contains moral values so that students not only learn about English but also character education.

There were two learning objectives of the game. They were as follows: 1) analyzing social functions and linguistic elements in simple narrative texts (knowledge); and 2) capturing the meaning of narrative text in the form of a simple short story (skill). The next phase was designing the lesson plan contained in the game. In the game, it was provided the narrative text and some practices to make the procedure follow the learning steps of CIRC.

\section{Expert Validation and Product Revision}

After the researcher developed the game, it was validated by the material and media experts. Questionnaires consisting of 24 statements were administered to the material experts and 26 statements to the media experts. To measure the agreement level between the experts, the researcher used Cohen's kappa technique using SPSS 17.00 because there were two experts of each validation. The measurement scale used in the questionnaires was Likert Scale in which the respondents were asked to respond each statement given by giving checklist $(\sqrt{ })$. The Likert Scale in this study was a 5-point scale that offered a range of answer options - (5) very good, (4) good, (3) enough, (2) poor, and (1) very poor. The experts also gave comments and suggestions toward the aspects assessed.

Based on the Kappa result of material experts, the value was .628 (see Table 2). It indicated that there was good agreement between the material experts. In addition, the value of agreement Kappa measure between the media experts was .642 (see Table 4) in which it can also be described as good agreement.

Table 2. The Result of the Agreement Level between Material Experts

\begin{tabular}{lcrrr}
\hline & \multicolumn{3}{c}{ Asymp.Std. } & \\
& Value & Error $^{\mathrm{a}}$ & Approx. $^{\mathrm{b}}$ & Approx. Sig. \\
\hline $\begin{array}{l}\text { Measure of Agreement } \\
\text { Kappa }\end{array}$ & .628 & .166 & 3.131 & .002 \\
$\mathrm{~N}$ of Valid Cases & & & & \\
\hline
\end{tabular}

Aspects assessed by the material experts were concept truth, materials depth, and implementation. The concept truth includes clarity of learning objectives, suitability of content with the target, and relevance of learning objectives with the curriculum, and relevance of content with learning objectives; the materials depth includes coverage of learning objectives, clarity of the content, actualization of the content, suitability of the exercise with the 


\section{Nina Sofiana}

content, coverage of the content, content depth, and ease of the game developed as learning media; the implementation includes game ease to understand, quality of the game in motivating the students, consistency between evaluation and learning objectives, quality of evaluation, clarity of exercise, suitability between evaluation and content, quality of feedback, clear logic flow, systematic content, level of students' interaction, level of students' participation, the accuracy of the game developed in delivering the material, the ability of the game in delivering the material. The validation was done by 2 experienced lecturers. They commented that the introductory duration before going into the game was too long. In addition, there were still some grammatical errors of some sentences made. In the Table 3 , it is the summary of each aspect assessed by the material experts.

Table 3. Material Experts Validation Result

\begin{tabular}{clc}
\hline No & Aspect & $\%$ \\
\hline 1 & Concept Truth & 87.5 \\
\hline 2 & Materials Depth & 82.9 \\
\hline 3 & Implementation & 88.5 \\
\hline & Average & 86.3 \\
\hline
\end{tabular}

Based on the results of the material experts' validation, it can be concluded that the assessment of material experts for the aspect of concept truth, materials depth, and implementation of the game was $86.3 \%$. It means that the developed game as learning media was categorized as a good game and needs some revisions.

Table 4. The Result of the Agreement Level between Media Experts

\begin{tabular}{|c|c|c|c|c|}
\hline & \multicolumn{3}{|c|}{ Asymp.Std. } & \multirow[b]{2}{*}{ Approx. Sig. } \\
\hline & Value & Error $^{\mathrm{a}}$ & Approx. $T^{b}$ & \\
\hline Measure of Agreement & .642 & .131 & 4.935 & .000 \\
\hline Kappa & & & & \\
\hline $\mathrm{N}$ of Valid Cases & 26 & & & \\
\hline
\end{tabular}

Then, the media experts test the media's feasibility of software engineering and visual communication. The media experts were experienced lecturers of science and technology faculty majoring in information and technology department. The software engineering includes effectiveness, efficiency, reliability, maintainability, usability, compatibility, clarity of instruction, accuracy of application type selection, reusability, integration of learning media program packets, clarity of trouble shooting, clarity of design program, clarity of installation instruction, language use, and feedback or 


\section{Nina Sofiana}

interaction; the visual communication includes simplicity, aesthetics, the choice of colour, the choice of typography, the choice of layout design, use of moving media (animation), use of navigation (layout), the choice of audio, and audio setting. Suggestions and improvements provided by the media expert were the addition of instructions clarity at each stage. Based on the results of validation of media experts, the game developed in this study was categorized as good media. Table 5 shows the summary of each aspect assessed by the media experts.

Table 5. Media Experts Validation Result

\begin{tabular}{ccc}
\hline No & Aspect & $\%$ \\
\hline 1 & Software Engineering & 81.3 \\
\hline 2 & Visual Communication & 74.5 \\
\hline & Average & 77.9 \\
\hline
\end{tabular}

After obtaining the suggestions and recommendations of material experts and media experts, the preliminary game developed was refined by referring to the scoring sheets provided by them. The revision included on the part of grammatical error and reduction of the introduction time, as well as on the media aspects as in clarity of instructions.

\section{Field Testing and Developing Final Product}

In the field testing, it consisted of limited and expanded try-out. The questionnaire for the field testing consisted of 27 statements and grouped into four aspects of programming, program security, user interaction and reaction, and learning. In this phase, the students were asked to express how much they agree or disagree with each statement. They had to select one of 4 options - (4) strongly agree, (3) agree, (2) disagree or (1) strongly disagree. The programming aspect included ease of application to be operated, introduction design clarity, aesthetics of application display, clues clarity, use of navigation, use of colours and fonts, image quality, and music back-sound quality. Then, in this study the program was safe if the application was not hanging if there was a usage error and the material content in application could not be changed or removed by the users. Meanwhile, the user interaction and reaction were categorized as good media if the application was interactive, easy to use, and did not make students bored. Finally, the learning aspect included clarity of learning menu and materials, material demands, use of language that was easy to understand, and application benefits.

The first try-out was administered to the ten students of grade $X$. It was conducted to determine the weakness of the game before it was tried out to the larger group. Then, the expanded try-out was conducted to one of the class of 


\section{Nina Sofiana}

grade $X$ consisting of thirty-three students. The results of the limited and expanded try-out can be illustrated in the Table 6.

Table 6. Limited and Expanded Try-Out Result

\begin{tabular}{cccc}
\hline No & Aspect & Limited (\%) & Expanded (\%) \\
\hline 1 & Programming & 77.2 & 81.1 \\
\hline 2 & Program Security & 85 & 85.5 \\
\hline 3 & User Interaction and Reaction & 77.2 & 80.6 \\
\hline 4 & Learning & 76.3 & 80.5 \\
\hline & Average & 78.9 & 81.9 \\
\hline
\end{tabular}

The results of limited try-out showed that the aspect of programming, user interaction and reaction, and learning on the game developed was good category. And for the program security aspect, the RPG application developed was a good category with a minor revision. Users, in which in this case was the students of grade $X$, suggested that the instructions for using this game should be more clarified so students knew what to do to move on to the next step. Colour and the font face should be adjusted to the background to make the text readable clearly. Then, after revision, based on the results of beta test of expanded try-out, it can be concluded that all aspects of the assessment showed good category and increased compared to the limited try-out. In conclusion, the students have good response toward the use of RPG in reading learning.

Lastly, the result of expanded try-out was used to develop the game in RPG application. The adventure in the game begins with two characters that are in a library and they find a door to open. Then, in the dark room, they meet an old people who tell them how to get out of this room. The old man gives instructions on how to get past some obstacles. The players will be sent back to the library if they can answer all questions. The obstacles include the reading text of narrative to read and comprehend, vocabulary building, and treasure hunt: story comprehension. The players are provided a text and they must understand well about the content of the text. They, then, have to complete the sentences with the appropriate vocabularies provided. The last, in treasure hunt activity, the players discuss the answer to questions about the story grammar. It refers to the key elements of the narrative text presented like main idea, characters, sequencing of events, and conclusion.

\section{DISCUSSION}

The objective of this study was to develop a game which can be used as a media in reading learning. Based on the problems faced by teachers and students in the learning implementation of reading skills, it is necessary to provide a learning media that can attract student learning interests. The media

Journal on English as a Foreign Language, 8(2), 170-188

Copyright (C) 2018 by JEFL, p-ISSN 2088-1657; e-ISSN 2502-6615 


\section{Nina Sofiana}

can be a game that interest students to learn. The game developed in this study was RPG. It is a genre of video game in which its main goal is to successfully complete one major storyline adventure. In addition, teachers should also apply appropriate learning methods in using the game to improve students' reading skills. CIRC is a learning method that can improve students' reading skills (Gupta \& Ahuja, 2014; Karafkan, 2015; Sofiana, 2015; Varışoğlu, 2016; Zainuddin, 2015). By relating the principles of CIRC and RPG application, it is expected that the learning process of reading skill can be implemented effectively and have a certain quality.

The material selected for the CIRC-based RPG was narrative text. It is one of lists of different text types included in the English curriculum for the tenth grade of vocational high school students (Kemendikbud, 2003). It was also chosen because the students' reading skill of narrative text was still not good. The purpose of this text type is to amuse or to entertain the reader with a story. It is a story with complication or problematic events and it tries to find the resolutions to solve the problems. An important part of narrative text is the narrative mode, the set of methods used to communicate the narrative through a process narration.

In adjusting the CIRC technique for the RPG application, basal-related activities, one principal feature of CIRC developed by the experts was taken out. In basal-related activities, before the students start the game, teachers firstly have to introduce the narrative text to each student. They, then, discuss the common story elements of narrative text like settings (where and when the story takes place), characters, problem or goal, plot (a series of events in which the characters try to solve a problem or achieve a goal), and resolution (the solution or achievement of a goal). By doing so, the students will be ready to complete the game by finishing the adventure.

The developed game was set to be played in a group consisting of two people. Therefore, the students can play this game in pairs in which they can do partner reading. Partner reading is one of the activities of CIRC as one of cooperative learning techniques. Both of them will discuss to comprehend the text. This activity allows the students help each other in comprehending the text. It makes them work together to achieve shared goals, in this case to accomplish the adventure of the game. It is in line with the cooperative learning principles in which it refers to teaching methods in which children work in small groups to help one another learn (Slavin, 2008). The students will have positive interdependence and face-to-face promotive interaction which means that the efforts s/he makes benefit not only for her/him, but also for her/his partner in the group. In addition, the obstacles that must be passed together in the developed game are able to develop their leadership skills. All members in 


\section{Nina Sofiana}

the group have mutual contribution to finish the game. It means that all players participate the decision making process. The activities in the game also build trust and open communication between players.

The result of validation from material experts indicated that the concept truth, materials depth, and implementation of media developed was categorized as good media. The learning objectives were clear and relevant with the curriculum of vocational high school (the 2013 Curriculum). The materials were also systematically and clearly arranged and matched the learning objectives. The exercises for the evaluation were in line with the learning objectives and materials, and had good and clear qualities. RPG as a medium of reading learning had a material depth and was easy to use. The use of RPG made students easier to understand the materials. It also could increase students' interest in learning, participation and interaction.

Moreover, the media experts validated the aspect of software engineering and visual communication. They mentioned that the program of the developed game could run smoothly, but the instructions are still less clear. The program could be redeveloped adjusting the other materials. The operating system of this RPG was also simple so it can be used without any special skills. The layout design, background, and animation picture were interesting, and the ideas were well casted.

Finally, the result of limited and expanded try-out showed that the overall scores were $>74 \%$ which meant that the developed RPG was eligible to use. The storyline adventure in the RPG makes the students have a great desire to understand the text in order to enable them to go through the game successfully until they can complete it. It indicates that game activity provides an excellent environment for language learning. Therefore, the players, or the students unconsciously learn English while playing game.

\section{CONCLUSION}

This study develops an alternative media in reading learning by adapting one of the three principle elements of CIRC by using RPG application. The developed game is computer application made using RPG movie maker which its content consists of two characters who have to finish an adventure to complete the game. In the game, players or students will find some hurdles to go through to complete it.

The results of media and materials experts validation shows that the game is good to use as media in teaching reading. Then, the students also have positive response toward the use of RPG in learning reading. They are interested in the developed game and have high motivation to use it in 


\section{Nina Sofiana}

learning. Thus, RPG application can be used as an alternative media in reading learning.

The product developed in this study adjusted only one of three principles of CIRC. Therefore, the adaptation of all principles has to be conducted to get maximum result. Then, the experimental study has to carry out to find out the significant difference between the reading skill achievement of the students taught using this RPG and those who are not.

\section{REFERENCES}

Brom, C., Sisler, V., \& Slavik, R. (2010). Implementing digital game-based learning in schools: augmented learning environment of ' Europe 2045 .' Multimedia Systems, 16(1), 23-41. https://doi.org/10.1007/s00530-009-01740

Cruz, J. Q. (2007). Video games and the esl classroom. The Internet TESL Journal, 13(3), 13-17. Retrieved from http://teslj.org/Articles/QuijanoVideoGames.html

DeHaan, J. (2011). Teaching and learning English through digital game projects. Digital Culture E Education, 3(1), 46-55.

Dewi, S. A. (2018). Authentic suplementary materials to foster reading skill of vocational high school students. In Proceedings of International Seminar on English language Teaching and Research (ELTAR) 2018 (pp. 804-811).

Dickinson, D. K., Griffith, J. A., Golinkoff, R. M., \& Hirsh-Pasek, K. (2012). How reading books fosters language development around the world. Child Development Research, 20(1), 1-15. https://doi.org/10.1155/2012/602807

Findawati, Y. (2014). Bahan ajar multimedia interaktif kewirausahaan SMK menggunakan model pembelajaran problem based learning. Jurnal Nasional Teknik Elektro Dan Teknologi Informasi (JNTETI), 3(4), 257-263.

Gupta, M., \& Ahuja, J. (2014). Cooperative integrated reading composition (CIRC): Impact on reading comprehension achievement in English among seventh graders. International Journal of Research in Humanities, Arts and Literature Journals, 2(5), 37-46.

Hussain, S. Y. S., Tan, W. H., \& Idris, M. Z. (2014). Digital game-based learning for remedial mathematics students: A new teaching and learning approach in Malaysia. International Journal of Multimedia and Ubiquitous Engineering, 9(11), 325-338. https://doi.org/10.14257/ijmue.2014.9.11.32

Iacovides, I., Aczel, J., Scanlon, E., Taylor, J., \& Woods, W. (2011). Motivation, engagement and learning through digital games. International Journal of Virtual and Personal Learning Environments, 2(2), 1-16. https://doi.org/10.4018/jple.2011040101

Irfan, Ihsan, D., \& Petrus, I. (2016). Using RPG video games to improve English 


\section{Nina Sofiana}

vocabulary achievement of the 8th graders of smp lti igm palembang. In Proceedings of the 2nd SULE - IC 2016 (pp. 591-606).

Karafkan, M. A. (2015). Investigating the effects of group investigation (GI) and cooperative integrated reading and comprehension (CIRC) as the cooperative learning techniques on learner's reading comprehension. International Journal of Applied Linguistics \& English Literature, 4(6), 1-8. https://doi.org/10.7575/aiac.ijalel.v.4n.6p.8

Kemendikbud. (2003). Permendikbud no 70 tentang kerangka dasar dan struktur kulikulum sekolah menengah kejuruan/madrasah aliyah kejuruan. Jakarta: Kemendikbud.

La Guardia, D., Gentile, M., Dal Grande, V., Ottaviano, S., \& Allegra, M. (2014). A game based learning model for entrepreneurship education. Procedia Social and Behavioral Sciences, 14(1), 195-199. https://doi.org/10.1016/.sbspro.2014.05.034

Nasab, M. Z., Esmaeili, R., \& Sarem, H. N. (2015). The use of teaching aids and their positive impact on student learning elementary school. International Academic Journal of Social Sciences, 2(11), 22-27.

Panoutsopoulos, H., \& Sampson, D. G. (2012). A study on exploiting commercial digital games into school context. Educational Technology and Society, 15(1), 15-27.

Preeti. (2014). Education and role of media in education system. International Journal of Scientific Engineering and Research, 2(3), 174-175. Retrieved from http://www.ijser.in/archives/v2i3/SjIwMTMxNTg=.pdf

Prensky, M. (2003). Digital game-based learning. ACM Computers in Entertainment, 1(1), 1-4.

Slavin, R. E. (2008). Cooperative learning, success for all, and evidence-based reform in education. Éducation et Didactique, 2(2), 151-159.

Sofiana, N. (2015). The impact of cooperative integrated reading and composition (CIRC) on the students' reading skill. In The 7th COTEFL International Conference (pp. 106-112).

Varışoğlu, B. (2016). Influence of cooperative integrated reading and composition technique on foreign students ' reading and writing skills in Turkish i. Academic Journal, 11(12), 1168-1179. https://doi.org/10.5897/ERR2016.2744

Wahyuni, S. (2017). Developing writing materials based on CTL approach for Indonesian EFL learners. Journal on English as a Foreign Language (JEFL), $7(1), 97-118$.

Zainuddin. (2015). The effect of cooperative integrated reading and composition technique on students' reading descriptive text achievement. English Language Teaching, 8(5), 11-21. https://doi.org/10.5539/elt.v8n5p11 


\section{Author's Brief CV}

Nina Sofiana is an English lecturer at the English Education Department of Islamic University of Nahdlatul Ulama Jepara. She completed her M.Ed. at Semarang State University, English Education Program in 2011. Her major interests are in TEFL. She can be contacted at ninasofiana@unisnu.ac.id.

Appendix 1

The Result of Material Experts' Validation

\begin{tabular}{|c|c|c|c|}
\hline \multirow{2}{*}{ No } & \multirow{2}{*}{ Aspect } & \multicolumn{2}{|c|}{ Score } \\
\hline & & Expert A & Expert B \\
\hline 1 & Clarity of learning objectives & 4 & 4 \\
\hline 2 & Suitability of content with the target & 4 & 5 \\
\hline 3 & Relevance of learning objectives with the curriculum & 4 & 4 \\
\hline 4 & Relevance of content with learning objectives & 5 & 5 \\
\hline 5 & Coverage of learning objectives & 4 & 4 \\
\hline 6 & Clarity of the content & 4 & 4 \\
\hline 7 & Actualization of the content & 4 & 4 \\
\hline 8 & Suitability of the exercise with the content & 4 & 5 \\
\hline 9 & Coverage of the content & 4 & 5 \\
\hline 10 & Content depth & 4 & 4 \\
\hline 11 & Ease of the game developed as learning media & 4 & 4 \\
\hline 12 & Game ease to understand & 4 & 4 \\
\hline 13 & Quality of the game in motivating the students & 5 & 5 \\
\hline 14 & $\begin{array}{l}\text { Consistency between evaluation and learning } \\
\text { objectives }\end{array}$ & 4 & 4 \\
\hline 15 & Quality of evaluation & 4 & 4 \\
\hline 16 & Clarity of exercise & 4 & 4 \\
\hline 17 & Suitability between evaluation and content & 4 & 4 \\
\hline 18 & Quality of feedback & 4 & 4 \\
\hline 19 & Clear logic flow & 5 & 4 \\
\hline 20 & Systematic content & 5 & 5 \\
\hline 21 & Level of students' interaction & 4 & 4 \\
\hline 22 & Level of students' participation & 5 & 5 \\
\hline 23 & $\begin{array}{l}\text { The accuracy of the game developed in delivering } \\
\text { the material }\end{array}$ & 5 & 5 \\
\hline 24 & The ability of the game in delivering the material & 5 & 5 \\
\hline & Total & 103 & 105 \\
\hline
\end{tabular}

Comments:

- The introductory duration before going into the game was too long.

- Check the grammatical error 
Developing cooperative integrated reading and composition-based role-playing game application as an alternative media in the reading learning

Nina Sofiana

Appendix 2

The Result of Media Experts' Validation

\begin{tabular}{|c|c|c|c|}
\hline \multirow{2}{*}{ No } & \multirow{2}{*}{ Aspect } & \multicolumn{2}{|c|}{ Score } \\
\hline & & Expert A & Expert B \\
\hline 1 & Effectiveness & 4 & 4 \\
\hline 2 & Efficiency & 5 & 4 \\
\hline 3 & Reliability & 4 & 4 \\
\hline 4 & Maintainability & 3 & 4 \\
\hline 5 & Usability & 4 & 4 \\
\hline 6 & Compatibility & 4 & 5 \\
\hline 7 & Clarity of instruction & 2 & 2 \\
\hline 8 & Accuracy of application type selection & 4 & 4 \\
\hline 9 & Reusability & 4 & 4 \\
\hline 10 & $\begin{array}{l}\text { Integration of Learning media program } \\
\text { packets }\end{array}$ & 4 & 5 \\
\hline 11 & Clarity of trouble shooting & 5 & 5 \\
\hline 12 & Clarity of design program & 5 & 5 \\
\hline 13 & Clarity of installation instruction & 4 & 4 \\
\hline 14 & Language use & 3 & 3 \\
\hline 15 & Feedback or interaction & 5 & 5 \\
\hline 16 & Suitability of the message and the target & 5 & 5 \\
\hline 17 & Creativity in casting ideas & 4 & 4 \\
\hline 18 & Simplicity & 4 & 4 \\
\hline 19 & Aesthetics & 3 & 3 \\
\hline 20 & The choice of colour & 3 & 3 \\
\hline 21 & The choice of typography & 3 & 3 \\
\hline 22 & The choice of layout design & 3 & 3 \\
\hline 23 & Use of moving media (animation) & 3 & 4 \\
\hline 24 & Use of navigation (layout) & 4 & 5 \\
\hline 25 & The choice of audio & 4 & 4 \\
\hline 26 & Audio setting & 4 & 4 \\
\hline & Total & 100 & 103 \\
\hline
\end{tabular}

Comment

1. Make instructions of each stage clearer 
Developing cooperative integrated reading and composition-based role-playing game application as an alternative media in the reading learning

Nina Sofiana

Appendix 3

The Questionnaire of the Try-Out

\begin{tabular}{cl}
\hline No & Statements \\
\hline 1 & The game is easy to use \\
3 & The intro design of the game is clear \\
4 & The game display is attractive \\
5 & The game is easy in the installation process \\
6 & The Navigation used in the game is easy to use \\
7 & The buttons on the game function properly \\
8 & The font colour matches the game background \\
9 & The type and size of the letters are appropriate and can be read clearly \\
10 & The choice of background in the game is suitable \\
11 & The colour combination is good \\
12 & The use of back-sound in the game is suitable \\
\hline 13 & The game is not hanging when I make mistake in use \\
14 & I cannot modify or remove the game content \\
\hline 15 & I can interact with the game well \\
16 & The game response to the answers I gave is good \\
17 & I am free to do the activities I want \\
18 & With this game, I am more passionate in learning English \\
19 & I understand the purpose of using this game \\
\hline 20 & The learning menu in this game is clear \\
21 & The material in this game is clear \\
22 & The questions given in this game are easy to understand \\
23 & The questions given in this game are in accordance with the material \\
& provided \\
24 & The material presented in this game is coherent \\
25 & The language used in this game is easy to understand \\
26 & This game helps me understand the material \\
27 & The material in this game adds to my insight about narrative texts \\
\hline
\end{tabular}

